\title{
Evaluasi Kinerja Pabrik Kelapa Sawit Dalam Produksi Energi Terbaharukan
}

\section{Performance Evaluation of Palm Oil Mills in Renewable Energy Production}

\author{
ARIF DWI SANTOSO \\ Peneliti Pusat Teknologi Lingkungan, BPPT \\ Gedung 820 Geostech, Kawasan Puspiptek Serpong, Tangerang Selatan \\ E-mail: arif.dwi@bppt.go.id
}

\begin{abstract}
Several alternative waste management innovations from oil palm mills with a capacity of 30 tons / year have been evaluated. These waste innovations are based on the most optimal renewable energy yield produced by oil palm mills, ie biogas, compost and pellets. The evaluation stage begins by collecting data from the operations of the common palm oil factories that is used as the data base-line. Furthermore, preliminary data is compared with the data of waste management innovation which is grouped into 3 (three) activities: (1) compost production from empty bunches, (2) biogas production from liquid waste treatment and (3) pellet production. The comparative results state that the plant's ability to process 1 ton of fresh fruit bunches can produce alternative renewable energy products either $207 \mathrm{~kg}$ of compost or 125 $\mathrm{kWh}$ of electricity or $125 \mathrm{~kg}$ pellets. This paper aims to evaluate the performance of palm oil mills in renewable energy production that is the most optimal in generating the largest profit margin. The results showed that based on the maximum profit potential obtained from each process of waste management, the percentage of the processed waste is about 19.8; 45.5 and $34.6 \%$ for the respective compost, biogas and pellet production. The processed waste will earn profit from renewable energy products of compost, biogas and pellet of as many as 6.1; 31.3 and 54.47 US\$ / ton respectively. The overall waste treatment requires operating cost of 2.34 US \$/ton and will result in a total profit of 91.89 US\$ / ton.
\end{abstract}

Keywords: waste, palm oil mill, renewable energy, performance evaluation

\begin{abstract}
ABSTRAK
Beberapa alternatif inovasi pengelolaan limbah dari pabrik kelapa sawit dengan kapasitas 30 ton/tahun telah dievaluasi. Alternatif inovasi limbah ini didasarkan pada hasil akhir energi terbarukan yang paling optimal yang dihasilkan oleh pabrik kelapa sawit, yakni berupa biogas, kompos dan pelet. Tahapan evaluasi diawali dengan mengumpulkan data kegiatan operasional pabrik kelapa sawit yang dijadikan sebagai data base line. Selanjutnya data awal tersebut dikomparasi dengan data inovasi pengelolaan limbah yang terbagi dalam kegiatan: (1) produksi kompos dari tandan kosong, (2) produksi biogas dari pengolahan limbah cair dan (3) produksi pellet. Hasil komparasi menyatakan bahwa kemampuan pabrik dalam mengolah 1 ton tandan buah segar dapat menghasilkan beberapa alternatif produk energi terbarukan yakni $207 \mathrm{~kg}$ kompos atau $125 \mathrm{kwh}$ listrik atau $125 \mathrm{~kg}$ pellet. Tulisan ini bertujuan untuk membandingkan produktifitas inovasi produksi energi terbarukan yang paling optimal dalam menghasilkan margin keuntungan yang paling besar. Hasil penelitian menyatakan bahwa berdasarkan pada potensi keuntungan maksimal yang diperoleh dari masing masih proses pengelolaan limbah maka prosentase limbah yang diolah adalah dengan prosentase $19,8 \% ; 45,5 \%$ dan $34,6 \%$. Prosesntase limbah yang diolah tersebut akan menghasilkan produk energi terbarukan berupa kompos, biogas dan pellet dengan nilai keuntungan sebesar 6,$1 ; 31,3$ dan 54,47 US\$/ton. Keseluruhan pengolahan limbah membutuhkan biaya operasional sebesar 2,34 US\$ dan akan menghasilkan total keuntungan sebesar 91.89 US\$/ton.
\end{abstract}

Kata kunci: limbah, pabrik kelapa sawit, energi terbarukan, evaluasi kinerja 


\section{PENDAHULUAN}

\subsection{Latar Belakang}

Pada tahun 2017, Gabungan Pengusaha Kelapa Sawit Indonesia (GAPKI) menyatakan bahwa produksi CPO industri kelapa sawit Indonesia sebesar 41,98 juta ton atau naik sekitar 18\% dari produksi di tahun 2016 yakni sebesar 35,57 juta ton ${ }^{(1)}$. Dengan pencapaian tersebut telah mempertahankan posisi Indonesia sebagai negara produsen terbesar CPO di dunia dengan prosentase share market sebesar $64 \%$ (2).

Produksi CPO Indonesia diperkirakan akan terus meningkat dalam beberapa dekade tahun ke depan. Dengan prediksi peningkatan luas lahan yang mencapai sekitar $5 \%$ per tahun, maka diperkirakan luasan lahan sawit Indonesai akan mencapai 13,3 juta ha pada tahun $2020^{(3)}$.

Data permintaan CPO dunia tiap tahun juga mengalami peningkatan yang signifikan. Data dari oil world statistik menyebutkan bahwa seiring dengan pertumbuhan penduduk yang meningkat, maka kebutuhan 17 jenis minyak nabati termasuk kebutuhan minyak yang dominan yakni CPO pada tahun 2020 nanti sebesar 236 juta ton ${ }^{(4)}$. Besaran permintaan CPO ini menunjukkan bahwa potensi pasar CPO sangat besar dan akan terus berkembang di masa depan. Prediksi pasar ini memberikan harapan dan sekaligus tantangan bagi pelaku industri kelapa sawit di Indonesia.

Pada sisi lain, pabrik kelapa sawit (PKS) masih terbentur oleh permasalahan lingkungan yang belum sepenuhnya terpecahkan. Masalah tersebut adalah adanya produk limbah yang dihasilkan selama proses produksi CPO yang berupa limbah padat dan limbah cair belum terselesaikan. Berdasarkan prosentase berat limbah dalam persen, PKS mengeluarkan limbah padat berupa: tandan kosong (22\%) dari porsi tandan buah segar, TBS), serat (13\%), cangkang $(4,5 \%)$, abu $(0.01 \%)$, dan limbah cair (palm oil mill effluent, POME) sekitar 0,62-0,77 $\mathrm{m}^{3} /$ ton TBS $(5,6,7,8,9,10)$.

Keberadaan limbah padat dan limbah cair ini berpotensi menimbulkan dampak pencemaran lingkungan dan dampak sosial pada akhirnya akan berakibat menggangu proses produksi dan menurunkan produktivitas dari PKS itu sendiri. Oleh karena itu limbah-limbah tersebut harus dimanfaatkan untuk menghasilkan produk samping yang menguntungkan atau diolah sebelum dibuang ke tempat pembuangan akhir atau saluran/selokan air umum.

Beberapa upaya pemanfaatan limbah PKS telah dilakukan, baik itu dilakukan hanya untuk melunasi kewajiban otoritas lingkungan maupun dengan tujuan komersial yakni untuk peningkatan produktifitas pabrik. Pemanfaatan tandan kosong dan serat dapat diproses menjadi kompos ${ }^{(11,12,13)}$, pemanfaatan POME menjadi $\operatorname{biogas}^{(14,15)}$, pemanfaatan tandan kosong dan serat untuk bahan pembakaran steam dan boiler ${ }^{(16,17,18)}$, pemanfaatan tandan kosong, serat dan cangkang untuk bahan produksi pellet ${ }^{(19,20)}$, dan pemanfaatan slugde ${ }^{(21,22)}$.

Pada paper ini akan dilakukan evaluasi dari beberapa pemanfaatan limbah PKS untuk produksi energi terbarukan. Dari evaluasi ini diharapkan akan menghasilkan rancangan inovasi pemanfaatan limbah PKS yang paling optimal baik untuk tujuan peningkatan produktifitas pabrik dan maupun untuk kelestarian lingkungan.

\subsection{Studi Literatur}

\section{Status industri Sawit Indonesia}

Perkembangan industri sawit di Indonesia masih mengalami beberapa kendala, baik itu kendala teknis yang terkait peningkatan produktivitas perkebunan dan pabrik maupun kendala non teknis. Pada masa dekade ini, kendala non teknis ini justru relatif lebih sulit diatasi karena wilayah permasalahannya berada di luar jangkauan kita yang banyak melibatkan stake holder dengan beragam berkepentingan.

Beberapa kendala non teknis, misalnya kendala dari intern dalam negeri seperti ketidakpastian hak guna usaha (HGU) perkebunan dengan terbitnya PP No. 57/2017 dan peraturan turunannya ${ }^{(23)}$, terbitnya beberapa perda yang kontraproduktif dengan perkembangan industri sawit(24) serta kampanye negatif dari NGO/LSM yang mempermasalahkan isu hak asasi manusia seperti child labour dan perampasan hak masyarakat adat(25).

Kendala non teknis dari luar negeri juga turut menambah rumitnya pengembangan industri sawit di Indonesia. Kampanye negatif dan isu hambatan dagang terhadap sawit Indonesia menjadi permasalahan yang harus segera diatasi agar target dan harapan perkembangan sawit Indonesia memenuhi harapan. Berbagai negara seperti Amerika Serikat tengah memberlakukan anti-dumping untuk biodiesel Indonesia(26), juga munculnya resolusi Parlemen Eropa yang menyerukan pelarangan biodiesel berbasis sawit karena dinilai masih menciptakan banyak masalah dari deforestasi, korupsi, pekerja anak, sampai pelanggaran $\mathrm{HAM}^{(27)}$. Negara India juga menaikkan pajak impor minyak sawit dua kali lipat di tahun 2017 dibanding dengan tahun 2016(28). Senat Australia kembali mengajukan RUU Competition and Consumer Amendment (Truth in Labeling - Palm Oi)(29).

Meski hambatan perdagangan yang dilakukan oleh berbagai negara sangat menekan perdagangan sawit Indonesia, namun ekspor sawit Indonesia meningkat cukup signifikan. Hal 
ini menunjukkan bahwa minyak sawit masih merupakan minyak nabati yang sangat vital bagi dunia dan akan terus dibutuhkan seiring dengan pertumbuhan penduduk dunia yang terus meningkat tiap tahunnya. Berbagai upaya menghambat pertumbuhan industri ini akan terus dilancarkan karena persaingan dagang minyak nabati yang semakin ketat. Dalam menghadapi kondisi seperti ini, pemerintah diharapkan dapat membantu dengan mengeluarkan regulasiregulasi yang produktif, yang dapat mendorong perkembangan industri sawit agar tetap menjadi mesin penghasil devisa terbesar dalam menyokong perekonomian Indonesia.

Di dalam pihak industri sendiri, upaya bertahan dari hambatan-hambatan tersebut adalah dengan tetap menjaga dan meningkatkan produktifitas industri dan melakukan upayaupaya untuk menjawab kampanye negative sawit, misalnya dengan memperbaiki proses produksi pabrik kelapa sawit lebih ramah lingkungan. Upaya minimasi limbah PKS merupakan salah satu bentuk campaign counter dari kampanye negatif yang selama ini dituduhkan(30). Pengelolaan limbah diharapkan juga dapat meningkatkan nilai tambah bagi pabrik.

\section{Pengelolaan Limbah Padat}

Kegiatan industri kelapa sawit mulai dari kegiatan budidaya hingga kegiatan produksi minyak sawit (CPO) menghasilkan berbagai limbah yang terdiri dari limbah padat, limbah cair dan limbah udara/gas. Limbah padat yang dominan pada PKS terdiri dari tandan kosong (empty fruit bunch), pelepah, cangkang (shell), serat (fiber), lumpur (wet decanter solid), abu (ash) dan lain-lain $(5,6,7,8,9,10)$.

Tandan kosong merupakan limbah dominan yang terbesar volumenya yang dihasilkan oleh pabrik minyak kelapa sawit (PKS). Proses terbentuknya tandan kosong dihasilkan dari sterilizer dan tippler. Jumlah tandan kosong yang dihasilkan dari setiap pemrosesan 1 ton TBS adalah berkisar 23\%(13). Limbah ini biasanya tidak dikelola dengan baik, pemanfaatannya masih terbatas hanya dibakar atau dibiarkan sebagai mulsa tanaman. Beberapa PKS memanfaatkan tandan kosong untuk dikompos dan dibuat pupuk kemudian dikembalikan ke perkebunan. Kemampuan tandan kosong sebagai pupuk ini dimungkinkan karena kandungannya yang tinggi akan selulosa dan lignin(31). Beberapa praktisi menyatakan bahwa kompos dari tandan kosong akan dapat mengatur kelembaban tanah, meningkatkan infiltrasi tanah, menambah bahan organik tanah, meningkatkan KTK tanah, menstabilkan temperatur tanah, memperbaiki struktur tanah, meningkatkan mikroba tanah dan mengendalikan laju aliran permukaan dan erosi tanah(32). Selain sebagai bahan kompos, tandan kosong juga dapat dimanfaatkan sebagai bahan bakar. Tandan kosong dikombinasikan dengan serat dan cangkang menjadi sumber bahan bakar boiler yang cukup efektif(33).

Cangkang merupakan limbah dihasilkan dari pemrosesan kernel inti sawit dengan bentuk seperti tempurung kelapa. Limbah ini biasanya digunakan sebagai bahan bahan arang, bahan bakar untuk boiler karena memiliki kandungan kalor yang relative tinggi yakni 3.500-4.100 $\mathrm{kkal} / \mathrm{kg}^{(34)}$. Cangkang berpotensi menjadi bahan bakar terbarukan yang lebih ramah lingkungan dibanding batu bara, karena batubara mengandung sulfur dan nitrogen sehingga pembuangan uap dari boiler akan menggangu kesehatan masyarakat ${ }^{(35)}$.

Serat merupakan limbah padat PKS dari sisa perasan buah sawit berupa serabut seperti benang. Limbah ini diperkirakan memiliki kandungan kalor yang tinggi bila dimanfaatkan sebagai bahan bakar boiler atau steam, karena mengandung protein dan lignin sekitar $4 \%$ dan $26 \%$ serta kandungan kalor sekitar 2.637-3.998 $\mathrm{kkal} / \mathrm{kg}^{(34)}$.

Lumpur sawit atau dikenal dengan solid decanter merupakan limbah hasil tirisan decenter dari limbah cair palm oil mill effluent (POME). Limbah ini berbentuk seperti lumpur, dengan kandungan berupa air $75 \%$, protein kasar $11,14 \%$ dan lemak kasar $10,14 \%{ }^{(34)}$.

\section{Pengelolaan Limbah Cair PKS}

Limbah cair yang dominan dari operasional PKS adalah POME. Limbah cair ini berasal dari serangkaian proses produksi CPO mulai dari tahap perebusan TBS, hingga pemisahan fraksi air dan fraksi minyak.

Volume total POME yang dihasilkan dalam proses produksi CPO atau biodiesel bervariasi jumlahnya tergantung pada beberapa hal, seperti jenis metode sterilisasi, umur dan jenis tanaman, kondisi tandan buah segar dan variasi musim. Secara umum perkiraan volume limbah pome adalah sekitar $0,62-0,77 \mathrm{~m}^{3} / 1$ ton $\operatorname{TBS}^{(5,6,7,8,8,90) \text {. }}$

Komposisi limbah POME terdiri dari $90-95 \%$ air, $0,6-0,7 \%$ minyak dan $4-5 \%$ padatan terlarut ${ }^{(36)}$. POME berasal dari 3 proses dalam produksi CPO yaitu proses sterilisasi tandan segar yang menghasilkan air kondensat (18\%), dari sentrifuge sludge (74,5\%) dan dari pencucian hidrosiklon $(30 \%)^{(5,8)}$.

POME yang dikeluarkan dari pabrik kelapa sawit memiliki karasteristik seperti yang disajikan pada Tabel 2. .

Volume limbah POME dengan volume dan kualitas di atas harus diolah sebelum dibuang ke saluran irigasi/sungai. Dari Tabel 2 terlihat bahwa kualitas dari limbah POME menunjukkan nilai 
yang masih jauh dari standar baku mutu yang ditetapkan oleh pemerintah.

Tabel 1. Karakteristik dari POME*

\begin{tabular}{llc}
\hline \multicolumn{1}{c}{ Parameter } & \multicolumn{1}{c}{ Range } & Standar** \\
\hline Suhu & $80-90$ & 45 \\
$\mathrm{pH}$ & $3,4-5,2$ & $6,0-9.0$ \\
Minyak $(\mathrm{mg} / \mathrm{L})$ & $130-18.000$ & 30 \\
BOD $(\mathrm{mg} / \mathrm{L})$ & $10.250-43.750$ & 100 \\
COD $(\mathrm{mg} / \mathrm{L})$ & $15.000-$ & 500 \\
& 100.000 & \\
Padatan terlarut $(\mathrm{mg} / \mathrm{L})$ & $5.000-54.000$ & 300 \\
Total N $(\mathrm{mg} / \mathrm{L})$ & $180-1.400$ & 200 \\
\hline${ }^{*}$ Lam et al., 2011(36) & & \\
${ }^{* *}$ No.5 /MENLH/2014 & &
\end{tabular}

POME telah dicoba dimanfaatkan sebagai pupuk dan pengairan. Beberapa perusahaan memanfaatkan limbah POME langsung diaplikasikan ke tanaman sawit, setelah dilewatkan dan diinkubasi dalam saluran/kolam dalam waktu tertentu, namun aplikasi ini terbukti menggangu pertumbuhan dan produktivitas tanaman sawit( ${ }^{(38)}$.

Untuk menjaga keberlanjutan pabrik, maka limbah POME tersebut harus dikelola sedemikian rupa sehingga nilainya berada di bawah nilai standart. Bila mencermati nilai kandungan $\mathrm{BOD}$ dan COD yang tinggi, maka POME dapat dikonversi menjadi biogas sebagai salah satu upaya produksi energi terbarukan yang sangat menjanjikan.

\subsection{Tujuan}

Tujuan paper ini adalah memberikan alternatif kombinasi pengelolaan limbah pabrik kelapa sawit yang dapat menghasilkan energi terbarukan yang paling optimal. Alternatif inovasi pengelolaan ini sekaligus diharapkan akan dapat meningkatkan produktifitas dan keberlanjutan kegiatan operasional pabrik kelapa sawit di Indonesia.

\section{BAHAN DAN METODE}

Penelitian ini memfokuskan pada perhitungan potensi keuntungan finansial yang dihasilkan dari perhitungan kombinasi beberapa pengelolaan limbah pabrik kelapa sawit. Data dikumpulkan dari beberapa literatur operasional pabrik kelapa sawit dengan kapasitas penanganan tandan buah segar (TBS) sebanyak 30 ton/hari.

Beberapa batasan yang diterapkan dalam penelitian ini antara lain:

- Biaya yang diperhitungan dalam perhitungan komparasi ini adalah biaya operasional produksi PKS untuk menghasilkan CPO. Biaya modal (CAPEX) dan biaya lain yang dikeluarkan yang bukan untuk kepentingan menghasilkan produk nilainya diabaikan.

- Keuntungan dan manfaat yang diperhitungkan adalah hasil pengelolaan limbah yang berupa energi terbarukan yang meliputi energi biogas, kompos dan pellet. Keuntungan lain seperti pengurangan emisi/ gas rumah kaca tidak diperhitungkan.

Data yang digunakan dari penelitian ini adalah data yang diadopsi dari data untuk kebutuhan life cycle assessment (LCA) dari pengolahan 1 ton TBS. Untuk memenuhi data ini, penulis mengumpulkan dan membandingkan data material, energi, dan limbah dari proses produksi CPO dari literatur yang up to date dan terpercaya.

Data dasar yang dijadikan sebagai dasar pembanding kajian disajikan dalam Gambar 1. Skema pemanfaatan limbah PKS dari pengolahan 1 ton TBS dengan tambahan energi minyak diesel $1 \mathrm{~kg}$. Serat dan cangkang (tanpa tankos) dimanfaatkan sebagai sumber bahan bakar boiler sehingga dihasilkan energi untuk steam pabrik serta dihasilkan tambahan energi sebesar 14,1 kWh. Limbah cair (POME) dikelola dalam unit system waste water treatment (WWT) sehingga limbah POME dapat digunakan untuk kebutuhan PKS dan dibuang ke saluran pembuangan umum(10).

Sebagai pembanding dari data dasar, ditawarkan 2 konsep inovasi pengolahan limbah PKS yaitu konsep pengolahan limbah padat (serat, tankos dan cangkang) sebagai pellet dan konsep pengolahan POME sebagai energi listrik.

Beberapa perubahan skema PKS pada konsep pengolahan limbah padat menjadi pellet adalah dengan menambahkan unit pengering bahan baku dan unit produksi pellet. Pada konsep ini kita membagi limbah padat, sebagian untuk konsumsi bahan bakar boiler sebagian lagi ditambah tankos untuk bahan material pembuatan pellet. Pada konsep ini semua material diperlakukan tahap pre-treatment dan pengeringan sebelum diproses oleh unit pembuat pellet ${ }^{(10)}$.

Pada konsep pengolahan POME menjadi energi listrik dilakukan beberapa perubahan pada penyediaan kolam yang berupa kolam tertutup (covered anaerobic lagoon) dan kolam pembangkit (facultative lagoon). Pada kolam yang pertama, POME diperam dan kolom airnya diaduk sehingga produksi gas dapat optimal untuk dapat dikonversi menjadi energi listrik. Pada kolam fakultatif berfungsi sebagai kolam pengolahan lanjutan dari lumpur POME. 


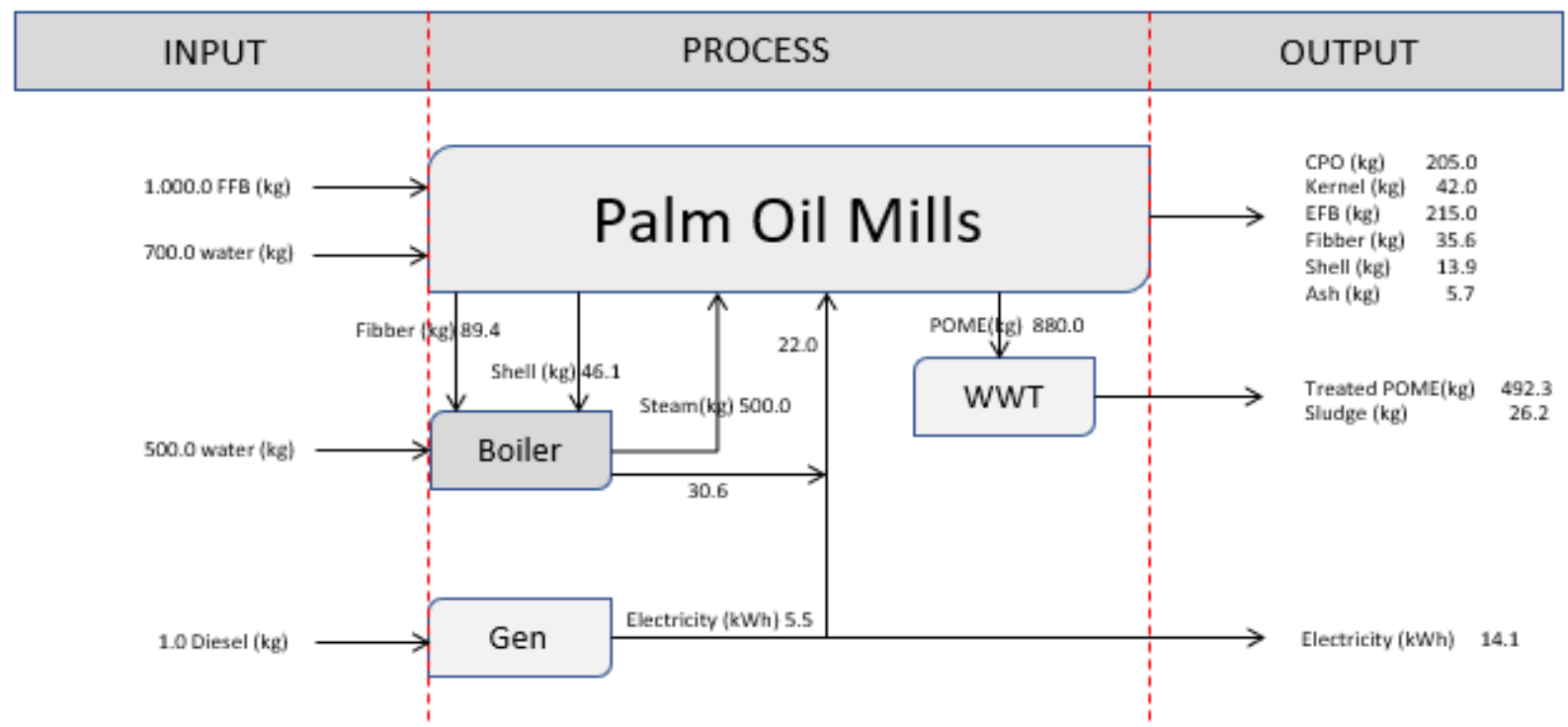

Gambar 1. Skema kegiatan produksi CPO dari suatu pabrik kelapa sawit (sumber: Garcia-Nunez et al., 2016 ${ }^{(19)}$, diadaptasi oleh penulis)

Dari kedua konsep dan konsep dasar akan didapatkan data yang meliputi data biaya operasional dan produk akhir yang dihasilkan. Data ini kemudian dilengkapi dengan data harga produk untuk dapat dikomparasikan.

Perhitungan optimalisasi dari inovasi pengolahan limbah PKS dilakukan dengan menggunakan pendekatan programming linier. Tahapan pengolahan data komparasi inovasi pengolahan limbah PKS dengan persamaan matematik ini adalah sebagai berikut:

1. Mendiskripsikan variabel yang akan digunakan dalam persamaan matematik

Variabel dan nilai yang digunakan adalah:

a : Pengolahan limbah untuk produksi kompos

b : Pengolahan limbah untuk produksi biogas

c : Pengolahan limbah untuk produksi pellet

$\mathrm{x}_{1}, \mathrm{x}_{2}, \mathrm{x}_{3}:$ : $\mathrm{kg}$ produk/1 ton TBS

$\mathrm{y}_{1}, \mathrm{y}_{2}, \mathrm{y}_{3}$ : Keuntungan optimal dari produk $\mathrm{x}_{1}, \mathrm{x}_{2}, \mathrm{x}_{3}$

2. Menyusun persamaan matematik

Untuk menetapkan jumlah limbah yang dikelola sehingga menghasilkan keuntungan yang optimal, maka perlu ditetapkan perbandingan antara jumlah limbah yang dikelola dengan keuntungan yang akan diperoleh. Untuk menentukan nilai tersebut variable-variabel yang terlibat disusun dalam matematik seperti di bawah ini.

$\mathrm{x}_{1}, \mathrm{x}_{2}, \mathrm{x}_{3} \geq 0$

$\mathrm{y}_{1}, \mathrm{y}_{2}, \mathrm{y}_{3} \geq 0$ $f(x, y)=X_{1} a_{+}+X_{2} b_{+}+X_{3} c \leq 1.000$

Keterangan:

$a=$ kompos

$b=$ biogas

$\mathrm{c}=$ pellet

3. Menetapkan perbandingan jumlah limbah yang diolah dengan keuntungan

Selanjutnya dilakukan perhitungan perbandingan antara jumlah biaya pengelolaan limbah PKS dengan jumlah keuntungan yang diperoleh. Keuntungan maksimal digunakan sebagai dasar untuk menentukan porsi bahan baku limbah yang diolah, sehingga menghasilkan penetapan volume limbah yang efisien.

\section{HASIL DAN PEMBAHASAN}

Perhitungan hasil pengolahan limbah padat dan limbah cair dengan memprioritaskan produksi energi terbarukan berupa kompos, biogas dan pellet pada masing-masing proses yang berbeda menghasilkan produk seperti pada tabel di bawah ini.

Tabel 2. Hasil pengolahan limbah kelapa sawit ${ }^{16}$, $19,20,36)$

\begin{tabular}{lccc}
\hline Variabel / Inovasi & Kompos & Biogas & Pellet \\
\hline Produk (ton) & 0.207 & 0.125 & 0.125 \\
\hline Biaya (\$/ton) & 1,77 & 1.62 & 3.39 \\
\hline Harga produk (\$/ton) & 32 & 92 & 123 \\
\hline Keuntungan (\$/ton) & 6,2588 & 11,29 & 14,951 \\
\hline
\end{tabular}

Pada Tabel 2 disajikan hasil produksi energi terbarukan untuk setiap proses pengolahan limbah PKS dengan satuan unit 1 ton TBS. Biaya 
proses pengolahan limbah terbesar diserap oleh proses produksi pellet yakni sebesar 3,38 US\$/ton pengolahan TBS. Tingginya biaya produksi pellet dimungkinkan adanya tambahan unit pengering bahan baku dan unit produksi pellet itu sendiri. Pada proses ini semua material limbah padat PKS diperlakukan tahap pretreatment dan pengeringan sebelum diproses oleh unit pembuat pellet(19). Tingginya biaya produksi pellet ternyata tidak menurunkan keuntungan, malah sebaiknya menjadikan produksi pellet sebagai proses yang paling banyak menghasilkan keuntungan yakni sekitar 14,95 US\$/ton TBS. Tingginya harga pellet sebesar 123 US\$/ton menjadi penyebab peningkatan margin yang signifikan. Demikian sebaliknya pada proses produksi kompos, meskipun biaya produksinya relative rendah yakni sekitar 1,77 US\$/ton TBS namun margin keuntungan yang dihasilkan paling kecil yakni sekitar 6,26 US\$ dikarenakan rendahnya produk kompos yang hanya 32 US\$/ton ${ }^{(19)}$.

Dari data keuntungan proses pengolahan limbah PKS dapat disimpulkan bahwa proses produksi pellet menjadi proses yang paling efisien dan menguntungkan(10,19,36). Namun, menimbang bahwa semua limbah PKS (tidak hanya limbah padat untuk pellet) harus diolah sehingga keberadaannya tidak mencemari dan menghambat kesinambungan PKS, maka diperlukan pembagian pengelolaan limbah tersebut. Pembagian limbah ini dilakukan karena keterbatasan biaya yang disediakan oleh PKS.

Perhitungan prosentase volume limbah PKS yang diolah berdasarkan biaya produksi dan hasil energi terbarukan yang paling optimal disajikan pada tabel di bawah ini.

Tabel 3. Hasil perhitungan penetapan prosentasi limbah yang diolah

\begin{tabular}{lccc}
\hline \multicolumn{1}{c}{ Inovasi } & Kompos & Biogas & Pellet \\
\hline Produk (ton) & 0.207 & 0.125 & 0.125 \\
\hline Biaya (\$/FU) & 0.242 & 0.335 & 0.702 \\
\hline Keuntungan (\$/FU) & 6.382 & 11.165 & 14.673 \\
\hline Penyederhanaan & 1 & 1.749 & 2.299 \\
\hline$\%$ & 19.806 & 34.648 & 45.537 \\
\hline Limbah (ton/FU) & 0.198 & 0.346 & 0.455 \\
\hline Produk (ton/FU) & 0.041 & 0.043 & 0.057 \\
\hline Biaya (\$/FU) & 0.038 & 0.067 & 0.087 \\
\hline Keuntungan (\$/FU) & 6.300 & 31.810 & 55.923 \\
\hline $\begin{array}{l}\text { Keterangan: } \\
\text { FU: Fungsional Unit }\end{array}$ & & &
\end{tabular}

Dasar yang digunakan untuk menentukan prosentase volume limbah adalah potensi keuntungan maksimal yang diperoleh dari masing masih proses pengelolaan. Nilai keuntungan ini kemudian disederhanakan dengan cara membandingkan masing masing nilai keuntungan dengan nilai keuntungan yang terendah. Dari hasil perhitungan tersebut dihasilkan nilai prosentase volume limbah PKS seperti disajikan dalam gambar di bawah ini.

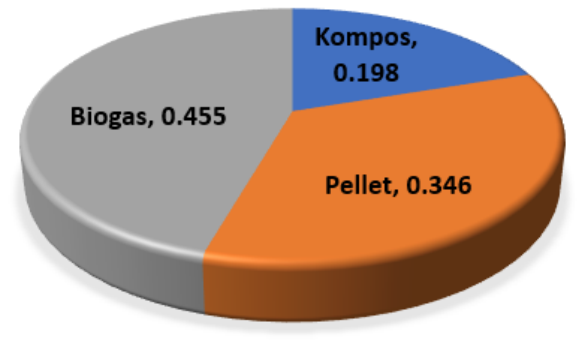

Gambar 2. Perhitungan prosentase volume limbah PKS

Untuk menghasikan keuntungan optimal dari proses pengolahan limbah PKS menjadi material energi terbarukan berupa kompos, biogas dan pellet adalah dengan mengatur prosentase limbah yang diolah dengan prosentase 19,8\%; $45,5 \%$ dan $34,6 \%$.

Selanjutnya dari masing masing volume limbah yang ditetapkan untuk diolah sesuai dengan biaya operasionalnya akan menghasilkan produk energi terbarukan berupa kompos, biogas dan pellet dengan nilai keuntungan sebesar 6,1 ; 31,3 dan 54,47 US\$/ton.

Perbandingan antara Limbah, Produk dan Keuntungan

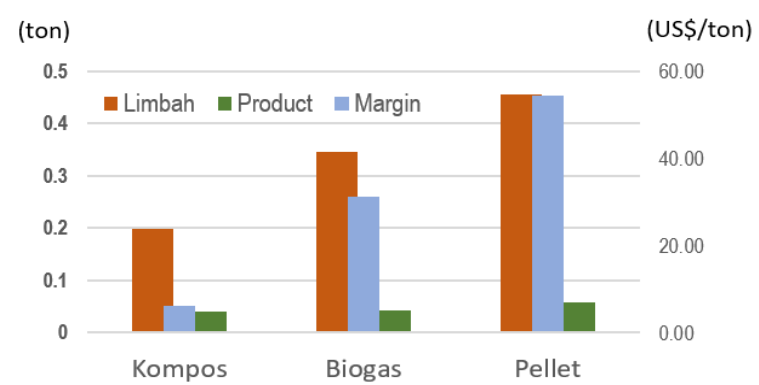

Gambar 3. Perbandingan volume limbah, produk dan keuntungan

Dengan penetapan jumlah limbah yang diolah seperti pada gambar 2, membutuhkan biaya operasional sebesar 2,34 US\$ akan menghasilkan total keuntungan sebesar 91.89 US\$/ton.

\section{KESIMPULAN}

Pengelolaan limbah PKS menjadi kegiatan prioritas perusahaan agar produktivitas dan kesinambulan PKS terjamin. Upaya peningkatan produktivitas PKS dalam pengelolaan limbahnya dengan mempertimbangkan margin keuntungan 
yang optimal adalah dengan mengolah limbah PKS menjadi produk enegi terbarukan berupa kompos, biogas dan pellet dengan perbandingan prosentase limbah yang diolah sebesar 19,8\%; $45,5 \%$ dan $34,6 \%$. Dengan prosentase pengolahan limbah tersebut, maka keuntungan yang diperoleh oleh PKS adalah sebesar 91,89 US\$/ton TBS.

\section{PERSANTUNAN}

Kepada Dr. Joko Prayitno Susanto, M.Sc dan Dr. Nawa Suwedi, M.Sc atas kerjasama dan bimbingan selama berada dalam tim penelitian kelapa sawit. Ucapan terima kasih juga penulis sampaikan kepada Karina Anggraeni, ST dan Priska Alfatri Hendrayanto, ST atas bantuannya dalam penyelesaian perhitungan persamaan matematik yang digunakan dalam analisis pada makalah ini.

\section{DAFTAR PUSTAKA}

1. Anonymous, (2018). Gapki. Memaknai Devisa Sawit 300 Trilyun Rupiah. http://www.sawit.or.id/memaknai-devisasawit-300-trilyun-rupiah/ diunduh 27 Maret 2018 jam 15.50 WIB.

2. Natawijadja, H. (2018). Indonesia Ranking Satu Dunia Penghasil Crude Palm Oil. http://palembang.tribunnews.com/2017/12/0 7/indonesia-ranking-satu-dunia-penghasilcrude-palm-oil. 28 Maret 2018 jam 07.58 WIB.

3. Hendaryanti, dkk. (2016). Statistik Perkebunan Indonesia, Kelapa sawit 20152017. Direktorat Jendral Perkebunan, 81 hal.

4. Anonymous, (2017). Crude palm oil market. https://www.oilworld.biz/t/publications/database. Diunduh pada 26 Maret 2018 jam 14.30.

5. Yusoff, S. (2006). Renewable energy from palm oil-innovation on effective utilization of waste, Journal of Cleaner Production 14,8793.

6. Kamahara, H., Hasanuddin, U., Widiyanto, A., Tachibana R., Atsuta Y., Goto, N., Daimon H., \& Fujie K. (2010). Improvement potential for net energy balance of biodiesel derived from palm oil: A case study from Indonesia practice, Biomass and Bioenergy 34,1818-1824.

7. Chua N.S. (1992). Optimal Utilization of Energy Sources in a Palm Oil Processing Complex. Porim Engineering News, 25, 3-6.

8. Lubis, A.U. (2008). Kelapa Sawit (Elaeis guineensis Jacq.) di Indonesia, edisi-2,
Pusat Penelitian Kelapa Sawit, Medan, 277301 hal.

9. Tabassum, S., Zhang, Y., \& Zhang, Z. (2015). An integrated method for palm oil mill effluent (POME) treatment for achieving zero liquid discharge - a pilot study. J. Cleaner Prod. 95, 148-155.

10. Saidu M., Yuzi A., Salim MR., Sumiati, Azman S., \& Abdullah N. (2013). Influence of palm oil mill effluent as inoculums on anaerobic digestion of cattle manure for biogas production. Bioresource Technology 141, 174-174.

11. Schuchardt, F., Wulfert, K., Darnoko, \& Herawan, T. (2008). Effect of new palm oil mill process on the efb and pome utilization. J. Oil Palm. Res. 155-126.

12. Krishnan, Y., et al. (2016). Co-composting of palm empty fruit bunch and palm oil mill effluent: microbial diversity and potential mitigation of greenhouse gas emission. Journal of clear production (2016), http://dx.doi.org/10.1016/j.clepro.2016.08.11 8.

13. Susanto, J.P., Santoso AD., \& Suwedi, N. (2017). Perhitungan potensi limbah padat kelapa sawit untuk sumber energy terbarukan dengan metode LCA. Jurnal teknologi Lingkungan, 18(2),165-172.

14. Kaewmai, R., H-Kittikum, A., \& Musikkavong, C. (2013). Alternative technologies for the reduction of greenhouse gas emissions from palm oil mills in Thailand. Int.Greenh. Gas Control 11, 141151.

15. Hasanudin, U., Sugiharto R., Haryanto, A., Setiadi, T., \& Fujie, K. (2015). Palm oil mill effluent treatment and utulization to ensure the sustainability of palm oil industries. Water science and technology, 72(7), 10891095.

16. Santoso, A.D., Suwedi, N., Pratama, R.A., \& Susanto, J.P. (2017). Energi terbarukan dan pengurangan emisi gas rumah kaca dari palm oil mill effluent. Jurnal teknologi lingkungan, 18(1), 88-95.

17. Chiew, Y.L., Shimada, S. (2013). Current state and environmental impact assessment for utilizing oil palm empty fruit bunches for fuel, fiber and fertilizer - a case study of Malaysia, Biomass Bioenegy, 51, 109-124.

18. Patthanaissaranukool, W., Polprasert, C., \& Englande Jr. (2013). Potential reduction of carbon emissions from crude palm 
production based on energy and carbone balances. Appl. Energy, 102, 710-717.

19. J.A. Garcia-Nunez, Rodrigues, D.T., Fontanilla, C.A., Ramirez, N.E., Lora, E.E.S., Frear, C.S., Stockle C., Arnonette J., \& Garcia-perez, M. (2016). Evaluation of alternatives for the evolution of palm oil mills into biorefineries. Biomass abd Bioenergy (2016). $\quad$ http://dx.doi.org/10.1016/j. biobioe.2016.15.020.

20. A.B. Nasrin, Y.M. Choo, W.S. Lim I., Joseph S. Michael, \& M Rohaya.H. (2011). Briquetting of empty fruit bunch fibre and palm shell as a renewable energy fuel. J. Eng. Appl. Sci.(6), 446-451.

21. Baharuddin, A.S., Hock L.S., Yusof M.Z., Rahman N.A., \& Shah U.K. (2010). Effects of palm oil mill effluent (POME) anaerobic sludge from $500 \mathrm{~m} 3$ of closed anaerobic methane digested tank on pressedshredded empty fruit bunch (EFB) composting process. African journal of Biotechnology 9(16),2427-2436.

22. Khairuddin, M.N., Zakaria A.J., Isa I.M., \& Nazri W M. (2016). The potential of treated palm oil mill effluent (POME) sludge as an organic fertilizer. Journal of Agricultural Science, 26(2), 141-154.

23. Sihombing M. (2018). INDUSTRI SAWIT: Devisa Rp298 Triliun, Prahara Sang Primadona Devisa. http://industri.bisnis.com/read/20180131/12/ 732792/industri-s. Diunduh 23 Maret 2018 jam 23.10.

24. Limberg G. (2018). Konflik lahan harus segera diselesaikan. http://www.industry.co.id /read/29045/konflik-lahan-sawit-harussegera-diselesaikan, diunduh pada 23 Maret 2018 jam 19.30.

25. Sitanggang, T. (2018). Refreksi Industri Kelapa Sawit Indonesia 2017 dan Prospek 2018. https://gapki.id/news/4140/refleksiindustri-kelapa-sawit-2017-dan-prospek2018. Diunduh 28 Maret 2018 jam 09.24

26. Enggartiasto L. (2018). Indonesia Bawa Isu Bea Masuk Impor AS Terkait Biodiesel ke WTO. https://www.wartaekonomi.co.id /read171591/indonesia-bawa-isu-beamasuk- impor-as-terkait- biodiesel-kewto.html. Diunduh 23 maret 2018 jam 11.13 WIB.

27. Silitonga, L.T. (2018). Biodiesel berbasis CPO: Ini Harapan Parlemen Eropa. http://industri.bisnis.com/read/20180122/12/ 729367/biodiesel-berbasis-cpo-ini-harapan- parlemen-eropa. Diunduh pada 23 Maret 2018. Jam 11.30 WIB.

28. Setiawan S.D.D. ( 2018). Pada 2017, Ekspor Minyak Sawit Indonesia Mencapai Rekor Tertinggi Sepanjang Sejarah. https://ekonomi.kompas.com/read/2018/01/3 0/172547126/pada-2017-ekspor-minyaksawit-indonesia-mencapai-rekor-tertinggisepanjang. Diunduh pada 22 Maret 2018 jam 20.20 WIB.

29. Putri, M.R. (2018). Indonesia Harus Buka Pasar Baru Sawit. http://republika.co.id /berita/ekonomi/pertanian/18/02/04/p3mnrv4 53-indonesia-harus-buka-pasar-baru-sawit. Diunduh pada 22 Maret 2018 jam 09.50 WIB.

30. Laoli N. (2016). Kementerian pertanian tangkis black campaign CPO lewat promosi. http://industri.kontan.co.id/news/kemtantangkis-black-campaign-cpo-lewat-promosi. Diunduh 15 Maret 20.00 WIB.

31. Mandiri, (2012). Manual Pelatihan Teknologi Energi Terbarukan, Jakarta, 2012, 61 hal.

32. Pahan I. (2006). Panduan Lengkap Kelapa Sawit Manajemen Agribisnis Dari Hulu Hingga Hilir, Bogor, 2006.

33. Nasrin A.B., Ma A.N. Chow M.C, Hamdan H., \& Choo Y.M. (2006). Blending of palm biomass and coal: an alternative fuel for power generation in Malaysia. Palm industries economic Journal, 6(2), 31-36.

34. Haryanti A., Norsamsi N., Putri S.F, Novy P.P. (2012). Studi Pemanfaatan Limbah Padat Kelapa Sawit. Konversi,3(2),20-29.

35. Purba, A.R., Akiyat, A.D. Koedadiri, Dja'far, E.S., Sutarta, Harahap I.Y. (2005). Budidaya Kelapa Sawit. Pusat Penelitian Kelapa Sawit, Medan. Hal. 1-2.

36. Lam M.K., \& Lee K.T. (2011). Renewable and sustainable bio energies production from palm oil mill effluent (POME): Win-win strategies toward better environmental protection, Biotechnology Advances 29, 124-141

37. Wu T.W., Wahab M.A., Jahim MJ., \& Anuar N. (2009). A holistic approach to managing palm oil mill effluent (POME): Biotechnological advances in the sustainable reuse of POME, Biotechnology Advances 27, 40-52. 